\title{
Conversion of an eastern Southland sheep farm to factory supply dairy pasture: changes and implications for production
}

MATT and IRENE KLEYNGELD

Arthurton

\section{Abstract}

The Kleyngelds sharemilk a 135-hectare dairy farm for Tasman Agriculture, converted from sheep in 1990.350 cows are wintered with total production being $41800 \mathrm{~kg}$ milkfat (90/91), $54000 \mathrm{~kg}$ (91/92), and projected $92 / 93,57000 \mathrm{~kg}$. One third of the farm is in newer ryegrass/clover, the remaining mainly browntop. Grass grown and grazed is recorded, so paddock performance can be monitored. The major result is variation in growth, 11 3 tonnes $/ \mathrm{DM}$. A grazing round of approximately 26 days suits all pastures for best performance. A balance is created between under- andovergrazing. Pasture is grazed to a base level of $1400 \mathrm{~kg} / \mathrm{ha} / \mathrm{DM}$, to ensure quick regrowth but no loss of quality. Regrassing is the major emphasis -- approximately 10-20 hectares are done a season. Ryegrasses and clover are used at $23 \mathrm{~kg} / \mathrm{ha}$. Pasture is sprayed and direct drilled with care taken in grazing for first season. Fertiliser complements regrassing. Over the last two years $400 \mathrm{~kg} / \mathrm{ha} 15 \%$ potassic super was applied, this season $600 \mathbf{~ k g} / \mathbf{h a}$ were applied. Nitrogen is used strategically from late winter to autumn according to soil temperature over the whole farm. There are flow on effects through winter and early spring. Limiting factors to conversion are management, fertility and grasses. Planning is needed to utilise resources for best returns.

K eywords dairy conversion, fertiliser, regrassing, sheep farm, dairy farm

\section{Introduction}

My name is Matt Kleyngeld. My wife Irene and I have been dairying for 9 years as contract and share fanners in Northland, mainly around Whangarei. In 1990 we came to Arthurton to sharemilk for Tasman Agriculture.

The property was taken over in 1990. being a wellfertiliscd sheep farm. It was fenced and a lane system installed. A complete water system was installed and a cowshed built. The property is 135 hectares effective.

Two seasons have been completed and the stock and production are as follows:
1990191350 cows wintered

52 replacementsreared

41800 kg milkfat: 400/ha, 164/cow

1991/92 350 cows wintered

100 replacements reared

54000 kg milkfat: 400/ha, 164 cow

* Projected

1992/93 355 cows wintered

loo replacements

$57000 \quad \mathrm{~kg}$ milkfat: 440/ha, 168/cow

'he young stock are contract grazed off the farm.

Pastures

One third of the farm was in relatively new grass, consisting of perennial ryegrasses, red andwhiteclovers and cocksfoot. The remainder of the farm was predominantly browntop. There is a major difference in performance between these pastures. The browntop pastures are low in energy and nutritional value. Combined with low growth rates these pastures lower production levels and lead to cow loss.

A monitoring programme has been in place covering pre-grazing and post-grazing levels over a range of paddocks to quantify grass production. It has run in conjunction with a Focus Farm concept within Tasman Agriculture to monitor the conversion of dry matter to milk, and management impact. A major result established was total grass grown. Our better pastures of ryegrasses and clovers grew 11 tonne DM and the poorest browntop pasture grew 3 tonne DM.

\section{Pasture management}

We found the following points were significant in our pasture management.

\section{Grazing round}

We have found that to achieve our best performance from poorer pastures it is necessary to have an average round of approximately 26 days throughout the season, 
varying with growth rates. Any longer than this allows the browntop to run to seed quickly and form a dense matt. Utilisation is quickly lost as milking cows find it unpalatable. If the round is much shorter than 18 days the browntop is again under stress and grass production is affected. Browntop pastures cannot withstand stress, whether it be grazing or climatic, to the degree that newer ryegrasses and clovers can.

\section{Residuals}

Along with optimum rounds we have found grazing levels to be very important. Our base level is $1400 \mathrm{~kg} /$ DM/ha, and we achieve this by grazing a paddock to that level in whatever time is necessary, and moving on. At $1400 \mathrm{~kg} / \mathrm{DM} / \mathrm{ha}$, the browntop is adequately grazed, and being in agrowing state will produce as soon as the cows leave the paddock. At lower levels time is needed to achieve a growing state and this is markedly increased during stress times such as spring and autumn.

\section{Nitrogen}

The use of nitrogenous fertilisers. mainly urea, is a significant part of our management system. We monitor soil temperature at a $100 \mathrm{~mm}$ depth with a thermometer. We begin nitrogen application at a soil temperature of $5^{\circ}$. Nitrogen is applied to the whole farm at $30-40 \mathrm{~kg}$ nitrogen/ha, and is then used strategically throughout the season at a rate of $20-25 \mathrm{~kg}$ nitrogen/ha, depending on grass growth rates.

We are finding that the use of nitrogen enables us to manipulate growth rates and so further guarantees our spring feeding levels as well as extending our lactation into early May. Nitrogen keeps pastures in a better growing condition. It also has a benefit of beiig a cheap source of feed relative to return.

In the first seasonnitrogen was applied in late spring but there was no measurable response as ground conditions were too wet and cold. Early-August applications benefit our farm as ground conditions are suitable. So far this season we have monitored at 15: 1 response from nitrogen, with grass growth meeting cow demand a month earlier in late September. Over last season response rates varied from 12: 1 to $25: 1$. It is necessary to spell pasture treated with nitrogen for a period of 14-21 days before grazing to prevent cows from becoming fidgety and suffering appetite loss because of excess nitrates.

There is a marked difference in response rates between dairy-type pastures and browntop pasture. The better pastures respond and grow more grass overall and the flow on effects last longer.

\section{Production}

We have found that our better-performing pastures "carry" our poorer pastures, and by mixing them in the grazing round there is not the dramatic fluctuation in daily milk production as might be expected.

\section{Improvements}

\section{Regrassing}

We have placed major emphasis for the increase of production and grass utilisation on regrassing. Twenty per cent of the farm has been regreased in the first two years. To this end, we graze off cows over winter and conserve little off the milking hectares, enabling us to regrass as many hectares as possible. We are hoping to do 15-20 ha this season, and this will continue.

Our grass mix has been basic and consists of Kara cocksfoot $(3 \mathrm{~kg})$, Greenstone and Nui ryegrasses (16 $\mathrm{kg}$ ), Huia and Tahora white clovers $(4 \mathrm{~kg}$ ), to total $23 \mathrm{~kg} /$ ha. This year's mix will include red clovers and one white but will otherwise remain the same. This will produce a strong sward of upright dairy-type pasture. Cows will readily utilise such pastures and convert them efficiently into milk or body weight. The red clovers respond well to our grazing system and after two years are very strong.

Our applicationofnew grass consists of spraying out pastures with Roundup at 3 litres/ha and direct drilling the seed one way. Fertiliser is applied with the main spread over the farm.

Great importance is placed on grazing new pasture for its first season. No supplement is made for two years. As soon as the grass cannot be pulled it is grazed to an even level and stock removed. It is then grazed every 10 15 days through to winter, by large numbers for a short time. It is not allowed to grow too long or grazed too short. Duriig winter it is grazed once and the following season is grazed around 18 days, regardless of volume. to encourage a strong healthy sward. Weeds are controlled as necessary. The new grasses are in the topperforming pastures, thus validating the need to regrass to increase production.

\section{Fertillser}

To complement regrassing a fertiliser programme must be put into place to meet the needs of the farm. The farm when converted had good soil fertility: a $\mathrm{pH}$ of 6 , Olsen $\mathrm{P}$ 16. K 9. Over the first two years the fertiliser applications consisted of $400 \mathrm{~kg} / \mathrm{ha}$ of $15 \%$ potassic super. This season the rate has been increased to $600 \mathrm{~kg} / \mathrm{ha}$. The 
current soil test reads: $\mathrm{pH}$ 6. Olsen P 22. K 11. In retrospect higher rates of fertiliser should have been applied from the beginning to bring the $\mathrm{P}$ and $\mathrm{K}$ levels up quickly.

A desired P level of between 30 and 35 is our target, thus increasing grass production and achieving better response rates from nitrogen application.

\section{Conclusion}

Forconversionof farms from sheep to dairy, the limiting factors consist of management, fertility and grass species.

Management must be able to implement policies to maximise returns from facilities and features available. They must be effective at converting grown feed into produce be it milk or body weight, as the most expensive feed is wasted feed.

Fertility levels and grass species play an important role. These must be improved or upgraded to the level at which the return on the investment is maximised. 